Document downloaded from:

http://hdl.handle.net/10251/56699

This paper must be cited as:

Gomez Mendoza, M.; Marín García, ML.; Miranda Alonso, MȦ. (2014). Two-channel dansyl/tryptophan emitters with a cholic acid bridge as reporters for local hydrophobicity within supramolecular systems based on bile salts. Organic and Biomolecular Chemistry. 12(42):8499-8504. doi:10.1039/c4ob01394h.

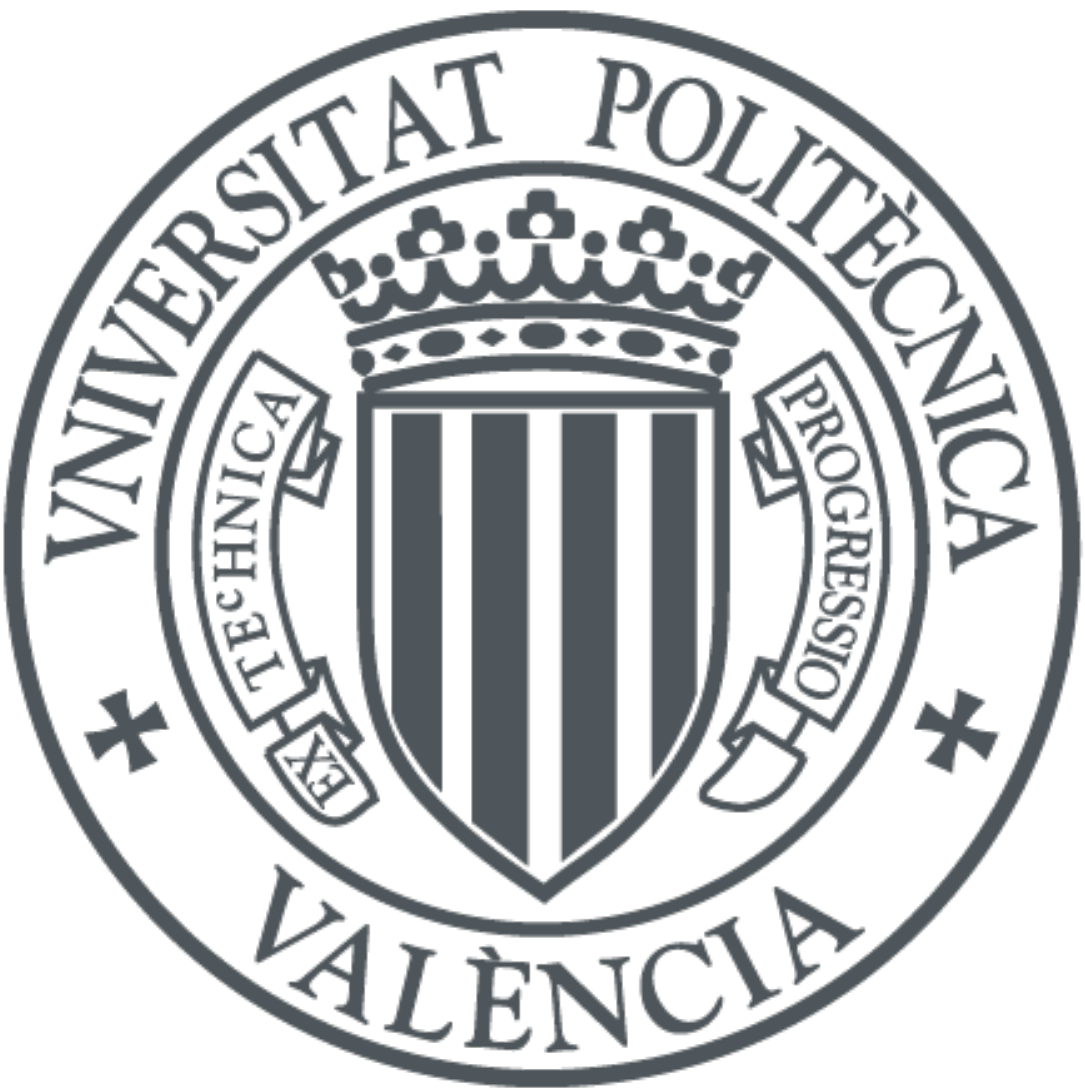

The final publication is available at

http://dx.doi.org/10.1039/c4ob01394h

Copyright Royal Society of Chemistry

Additional Information 


\title{
Two-channel Dansyl/Tryptophan Emitters with a Cholic Acid Bridge as Reporters for Local Hydrophobicity within Supramolecular Systems Based on Bile Salts
}

\author{
M. Gomez-Mendoza, ${ }^{a}$ M. Luisa Marin ${ }^{a, *}$ and Miguel A. Miranda ${ }^{a, *}$
}

The aim of the present work is to develop two-channel emitters to probe local hydrophobicity by means of fluorescence quenching within different biomimetic supramolecular environments. To achieve this goal, the dansyl (Dns) and tryptophan (Trp) fluorophores have been covalently attached to cholic acid (CA) in order to ensure simultaneous incorporation of the two emitting units into the same compartment. In principle, the two fluorophores of the synthesized Dns-CA-Trp probes could either exhibit an orthogonal behavior or display excited state interactions. The fluorescence spectra of 3 $\beta$-Dns-CA-Trp showed a residual Trp emission band at $c a .350 \mathrm{~nm}$ and an enhanced Dns maximum in the 500-550 $\mathrm{nm}$ region. This reveals a partial intramolecular energy transfer, which is consistent with the Dns and Trp singlet energies. Thus, the two photoactive units are not orthogonal; nevertheless, 3 $\beta$-Dns-CA-Trp seems appropriate as two-channel reporter for the supramolecular systems of interest. Fluorescence quenching of 3 $\beta$-Dns-CA-Trp by iodide (which remains essentially in bulk water) was examined within sodium cholate, sodium taurocholate, sodium deoxycholate and mixed micelles. Interestingly, a decrease in the emission intensity of the two bands was observed with increasing iodide concentrations. The most remarkable effect was observed for mixed micelles, where the quenching rate constants were one order of magnitude lower than in solution. As anticipated, the quenching efficiency by iodide decreased with increasing hydrophobicity of the microenvironment, a trend that can be correlated with the relative accessibility of the probe to the ionic quencher.

\section{Introduction}

Biomimetic assemblies provide specific microenvironments able to modulate the behavior of photoactive molecules. Transport proteins (serum albumins and $\alpha_{1}$-acid glycoproteins) have often been employed as hosts for drugs or other ligands containing appropriate chromophores. ${ }^{1}$ Although much less explored, bile salts (BS) are biomimetic supramolecular systems with great potential in the field. They are water soluble amphiphilic steroids that tend to aggregate, due to an initial interaction through the lipophilic $\beta$-face. We have recently reported on the use of photoactive probes to construct speciation diagrams of different BS and to monitor the changes from solution to primary and secondary aggregates. ${ }^{2,3}$ Thus, BS can provide distinct supramolecular microenvironments that tune the excited state properties of guest molecules and can be used as nanometric reactors for a variety of photochemical processes. ${ }^{4,5}$ Mixed micelles (MM) are formed upon addition of BS to unilamellar vesicles of cholesterol $(\mathrm{Ch})$ and lecithin, becoming the predominating species at high BS concentrations (typically $30 \mathrm{mM}$ ). ${ }^{6}$ During the formation of MM, BS and lecithin orient their hydrophilic moieties to the aqueous phase, keeping their hydrophobic regions in the MM interior, where Ch is efficiently solubilized. Moreover, MM are able to solubilize dietary lipids, therefore they play a pivotal role along the digestive system. ${ }^{7,8}$ This capability has been exploited to use MM as nanocarriers for pharmaceutical purposes. ${ }^{9-17}$ In this context, we have recently employed photophysical techniques, such as time-resolved fluorescence and laser flash photolysis, to demonstrate encapsulation of several drugs within MM. $^{18}$

In a preliminary communication, we have shown that cholic acid (CA) derivatized with a 4-nitrobenzo-2oxa-1,3-diazole (NBD) chromophore exhibits a significant stereodifferentiation in the quenching by tryptophan (Trp) upon incorporation into sodium cholate (NaCA) aggregates. ${ }^{19}$ Nevertheless, photoactive dansyl derivatives (Dns-CA) proved to be more sensitive to the microenvironment than the NBD-CA analogs. In addition to the abovementioned application for constructing the speciation diagrams of $\mathrm{BS},{ }^{2,3}$ Dns-labeling has revealed efficient incorporation of $\mathrm{Ch}$ into MM. ${ }^{8}$

Dual fluorescence probes are valuable tools as sensors for a variety of analytes in environmental or biological applications. Typical examples are those based on the appearance of exciplex or twisted intramolecular charge transfer (TICT) bands, together with the normal emission from locally excited states. ${ }^{20}$ Although probes of this type display remarkable medium-dependent behavior, their applicability may be hampered in some cases by the difficulty to achieve selective excitation of each emission channel. In 
addition, their limited solubility in different compartments of certain microheterogeneous systems may constitute an experimental drawback.

Herein we want to introduce new two-channel emitters for the study of fluorescence quenching by iodide anion within different environments such as BS and MM. Since the quencher remains in water, the rate constants determined for the process would provide a quantitative indication of the local hydrophobicity. ${ }^{21}$ To achieve this goal, the two fluorophores are covalently attached to the CA skeleton ensuring simultaneous incorporation of the two units into the supramolecular entities. This way, possible variations in the quenching rate constants due to a different location of the probes would be prevented.

\section{Results and discussion}

\section{Synthesis of the two-channel dansyl/tryptophan emitters}

The synthetic strategy developed to prepare the new probes containing simultaneously the two chromophores

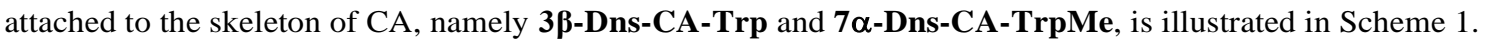

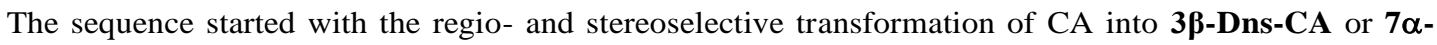
Dns-CA, following a methodology already optimized in our group. ${ }^{22}$ Treatment of these synthetic intermediates with $(S)$-tryptophan methyl ester hydrochloride $((S)$-TrpMe $\cdot \mathrm{HCl})$ yielded the corresponding amide between the carboxylic acid moiety of CA and the amino group of Trp. Final deprotection was only

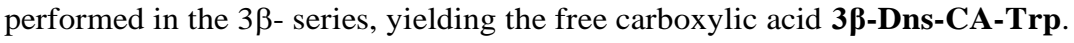

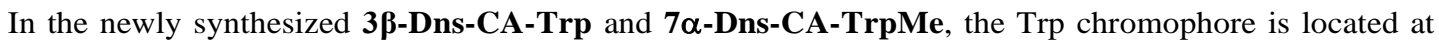
the lateral chain of CA, while the Dns group is linked to different positions of the skeleton; this allows analyzing the influence of the interchromophoric distance on the photophysical properties. The

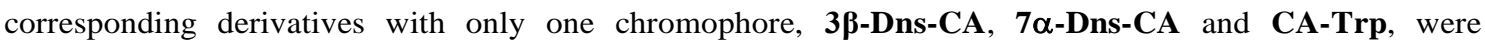
prepared as indicated in the Scheme, to be used as controls.

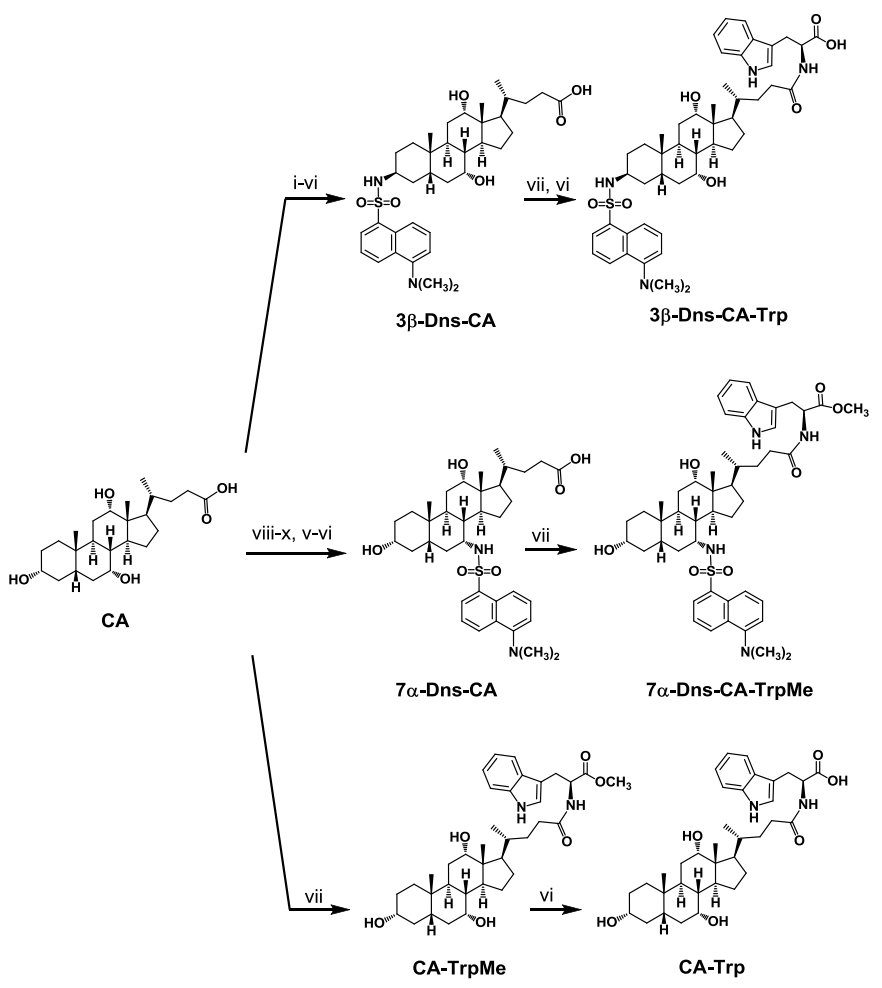

Scheme 1. Reagents and conditions: (i) $\mathrm{MeOH}, \mathrm{HCl}, \mathrm{DMP}, \mathrm{rt}$; (ii) $\mathrm{MsCl}$, pyridine, $\mathrm{N}_{2}$, rt; (iii) $\mathrm{NaN}_{3}, \mathrm{DMF}$, $\mathrm{N}_{2}, 100{ }^{\circ} \mathrm{C}$; (iv) Pd-C 10\%, $\mathrm{HCO}_{2} \mathrm{NH}_{4}, \mathrm{AcOEt}: \mathrm{MeOH}, 80{ }^{\circ} \mathrm{C}$; (v) Dns-Cl, Et ${ }_{3} \mathrm{~N}, \mathrm{DMF}, \mathrm{N}_{2}, \mathrm{rt}$; (vi) $\mathrm{KOH}$, $\mathrm{MeOH}$, rt; (vii) (S)-TrpMe-HCl, EDC, DIEA, 4-PrPy, $\mathrm{CH}_{2} \mathrm{Cl}_{2}, \mathrm{~N}_{2}, 0{ }^{\circ} \mathrm{C}$ to rt; (viii) NBS, $\mathrm{NaHCO}_{3}$ (aq), rt; (ix) $\mathrm{NaBH}_{3} \mathrm{CN}, \mathrm{NH}_{4} \mathrm{OAc}, \mathrm{MeOH}, \mathrm{rt}$; (x) $\mathrm{MeOH}-\mathrm{HCl}$, rt. 
In a first stage, the photophysical properties of the two dyads were studied to analyze the degree of communication between the two emitting units as a function of the interchromophoric distance. In principle, the Dns and Trp fluorophores could either exhibit an orthogonal behavior or display excited state interactions, depending on their position at the steroidal skeleton and on their relative spatial arrangement.

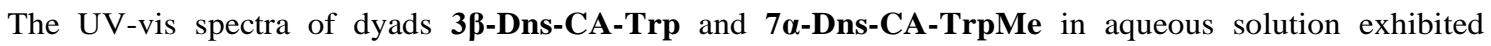
maxima around 330 and $280 \mathrm{~nm}$, mainly due to the contribution of the Dns and Trp chromophores, respectively (see SI, Figure S1). The fluorescence spectra were recorded upon excitation at $\lambda_{\mathrm{exc}}=290 \mathrm{~nm}$. In

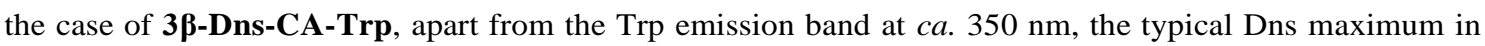
the $500-550 \mathrm{~nm}$ region was also observed (Figure 1). This is interesting, because the appearance of two bands in the spectrum allows using this dyad as a two-channel emitting probe. By contrast, when Dns was attached at $7 \alpha$ (7 $\alpha$-Dns-CA-TrpMe) only the long-wavelength emission was observed. Control experiments

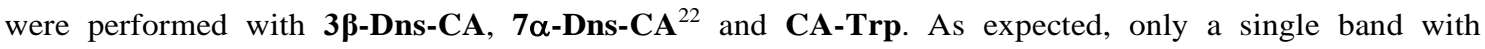
maximum at 355 (Trp) or $530 \mathrm{~nm}$ (Dns), was observed in all cases. Furthermore, 1:1 mixtures of 3ß-Dns-CA or $7 \boldsymbol{\alpha}$-Dns-CA plus CA-Trp gave emission spectra indistinguishable from the simple addition of the components.

Thus, a significant reduction was observed for the Trp fluorescence intensity at $355 \mathrm{~nm}$ in the case of $\mathbf{3 \beta}$ Dns-CA-Trp, revealing a partial intramolecular energy transfer. Moreover, a complete disappearance of the Trp band was noticed for 7 $\boldsymbol{\alpha}$-Dns-CA-TrpMe, indicating full intramolecular energy transfer in this dyad. This is consistent with the singlet energies determined for 3及-Dns-CA and CA-Trp, which are 280 and 386 $\mathrm{kJ} \mathrm{mol}^{-1}$, respectively. The observed differences suggest a Förster mechanism, ${ }^{23}$ whose efficiency depends on the relative donor-acceptor distances. In fact, applying Förster equations, 53\% energy transfer in the case of 3及-Dns-CA-Trp would correspond to a distance of $32 \AA$, in reasonable agreement with the estimation using molecular models. ${ }^{24,25}$

Thus, the two photoactive units are not orthogonal in the dyads, as evidenced by the existing excited state interactions; nevertheless, they seem appropriate as probes for the supramolecular systems of interest, and in particular, 3ß-Dns-CA-Trp shows potential as a two-channel emitter.

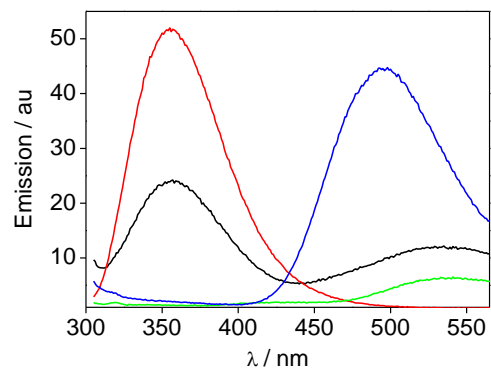

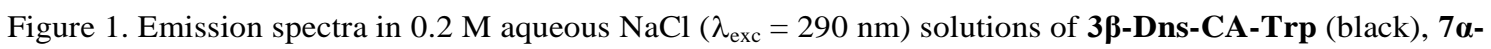
Dns-CA-TrpMe (blue), CA-Trp (red) and 3ß-Dns-CA (green).

Before starting the quenching experiments, the photobehavior of the probes was examined within $\mathrm{NaCA}$ $300 \mathrm{mM}$, sodium taurocholate (NaTCA, $300 \mathrm{mM}$ ), sodium deoxycholate (NaDCA, $75 \mathrm{mM}$ ), and mixed micelles (MM). The UV-vis spectra did not change upon incorporation into the supramolecular entities; however, when the emission was recorded upon $290 \mathrm{~nm}$ excitation, a partial energy transfer was again

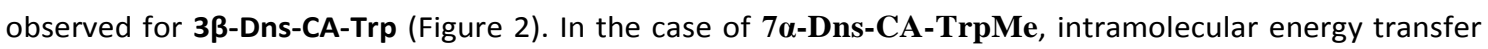
was fully efficient. The main differences in the shape and position of the $\mathbf{3} \beta$-Dns-CA-Trp emission band when compared to the results in solution can be attributed to the more lipophilic nature of the aggregates, which is associated with a higher fluorescence quantum yield and a blue shifted maximum. ${ }^{2,3}$ Moreover, the rigid structure of the binding sites may limit the degrees of freedom, causing small changes in the interchromophoric distance and hence in the energy transfer efficiency. The relevant intermolecular control experiments using 1:1 mixtures did not exhibit a significant energy transfer, indicating that at the concentrations used the two separate chromophores are housed apart in different compartments. 


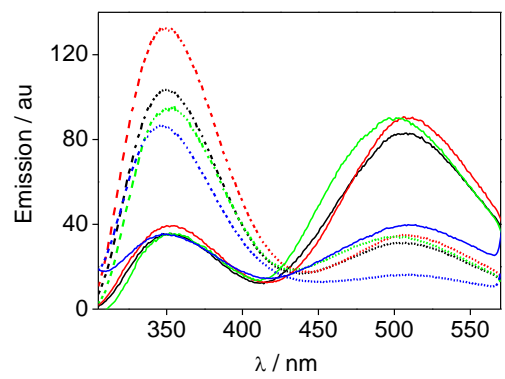

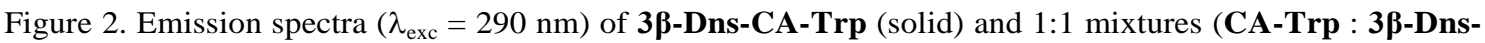
CA) (dashed) within different microenvironments: NaCA, $300 \mathrm{mM}$ (black); NaTCA, $300 \mathrm{mM}$ (red); NaDCA, $75 \mathrm{mM}$ (green) and MM (blue).

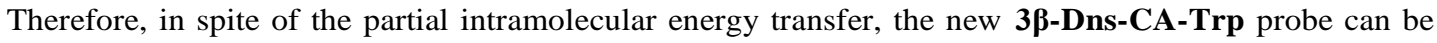
employed as a two-channel emitter to perform quenching experiments within supramolecular microenvironments.

\section{Fluorescence quenching}

Initially, fluorescence quenching of 3及-Dns-CA-Trp was investigated in solution $(15 \mu \mathrm{M})$ and compared to the results obtained with the intermolecular 1:1 mixture (CA-Trp : 3及-Dns-CA). Interestingly, a decrease in the emission intensity of the Trp and Dns bands was observed with increasing iodide concentrations in both cases (Figures 3A-B). The Stern-Volmer plots for quenching of both chromophores were obtained from the relative emission at the corresponding maxima $v s$ iodide concentration (Figure 3C). The singlet lifetimes were $\sim 6.0$ and $\sim 5.0 \mathrm{~ns}$ for the Trp and Dns chromophore, respectively. The quenching rate constants, determined from the slopes of the Stern-Volmer plots were higher for $\operatorname{Trp}\left(2.0 \times 10^{9} \mathrm{M}^{-1} \mathrm{~s}^{-1}\right)$ than for Dns $(7.4$ $\left.\mathrm{x} 10^{8} \mathrm{M}^{-1} \mathrm{~s}^{-1}\right)$ either in the dyad or as separate chromophores in the mixture $\left(2.5 \times 10^{9} \mathrm{M}^{-1} \mathrm{~s}^{-1}\right.$ and $8.0 \times 10^{8} \mathrm{M}^{-}$ ${ }^{1} \mathrm{~s}^{-1}$, respectively).

Next, different BS, namely NaCA (300 mM), NaTCA (300 mM) and NaDCA (75 mM), as well as mixed micelles (MM) were used as hosts to investigate quenching by iodide within different supramolecular microenvironments. Fluorescence quenching experiments were performed in parallel with 3及-Dns-CA-Trp and with the 1:1 mixture (CA-Trp : 3及-Dns-CA) all at $15 \mu \mathrm{M}$. The values for the fluorescence quenching rate constants, $k_{\mathrm{q}}{ }^{\mathrm{S}}\left(\mathrm{M}^{-1} \mathrm{~s}^{-1}\right)$, were determined from the slopes of the Stern-Volmer plots (Figure 3C) and are given in Table 1. As in solution (see above) the values were always higher for Trp than for Dns irrespective of the microenvironment. Moreover, a significant decrease of $k_{\mathrm{q}}{ }^{\mathrm{S}}$ with increasing hydrophobicity of the host was observed, indicating that the probes were largely incorporated into the supramolecular system, thus becoming less accessible to iodide.
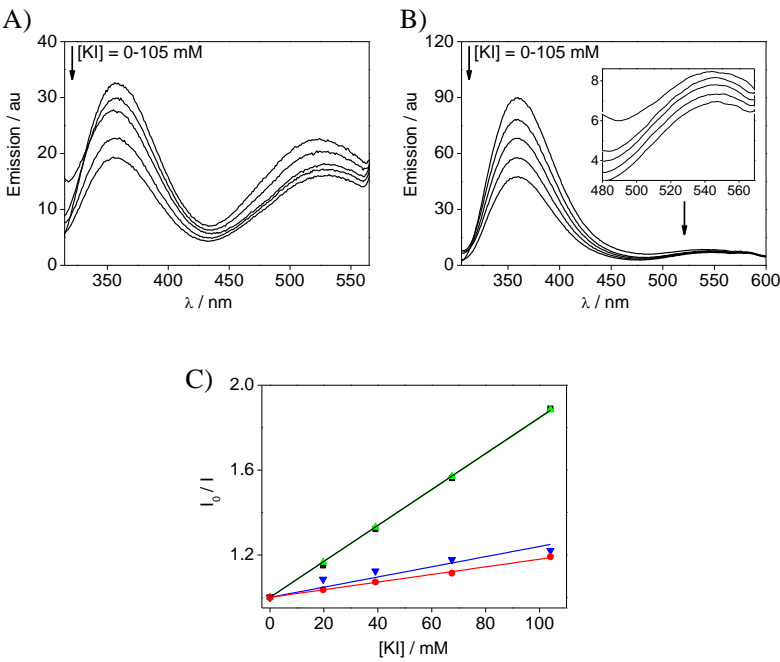
Figure 3. Changes in the emission spectra $\left(\lambda_{\mathrm{exc}}=290 \mathrm{~nm}\right)$ upon addition of increasing concentrations of KI

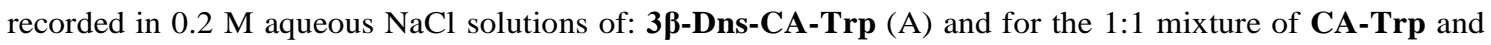

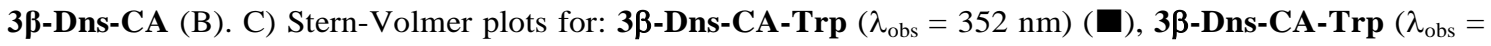

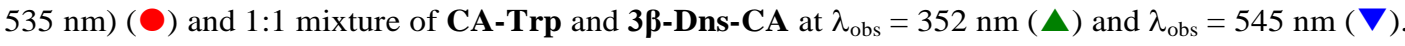

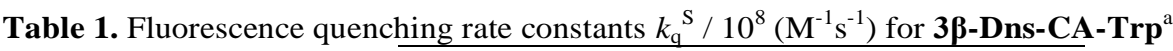

\begin{tabular}{ccc}
\hline \multicolumn{3}{c}{$\boldsymbol{k}_{\mathbf{q}}^{\mathbf{S}} / \mathbf{1 0}^{\mathbf{8}}\left(\mathbf{M}^{-1} \mathbf{s}^{-\mathbf{1}}\right)$} \\
\hline $\begin{array}{c}\text { Supramolecular } \\
\text { system }\end{array}$ & $\lambda_{\mathrm{obs}}=352 \mathrm{~nm}$ & $\lambda_{\mathrm{obs}}=550 \mathrm{~nm}$ \\
\hline Solution & $20.50 \pm 0.07$ & $7.40 \pm 0.03$ \\
NaTCA $(300 \mathrm{mM})$ & $6.50 \pm 0.02$ & $3.10 \pm 0.07$ \\
$\mathrm{NaCA}(300 \mathrm{mM})$ & $3.06 \pm 0.05$ & $1.45 \pm 0.03$ \\
$\mathrm{NaDCA}(75 \mathrm{mM})$ & $2.50 \pm 0.03$ & $0.80 \pm 0.01$ \\
$\mathrm{MM}$ & $2.00 \pm 0.05$ & $0.90 \pm 0.03$ \\
\hline
\end{tabular}

a The experiments were performed three times, and the errors correspond to average deviations.

It can be anticipated that the new two-channel emitter 3 $\beta$-Dns-CA-Trp can, in principle, be employed to assess hydrophobicity of other supramolecular systems of biological interest by comparing the obtained $k_{q}$ values with the ones reported in Table 1.

\section{Conclusions}

The new two channel emitter $3 \beta$-Dns-CA-Trp has proven to be an appropriate reporter for local hydrophobicity in supramolecular systems, such as NaCA, NaTCA, NaDCA and MM. Fluorescence quenching by iodide anion, which remains essentially in bulk water, is observed with medium-dependent rate constants. The process is consistently faster for Trp than for Dns in all systems, which must be related to the intrinsic nature of both chromophores. The quenching efficiency by iodide decreases with increasing hydrophobicity of the

microenvironment, in the following order: solution $>\mathrm{NaTCA}>\mathrm{NaCA}>\mathrm{NaDCA} \approx \mathrm{MM}$. This trend can be correlated with the relative accessibility of the probe to the ionic quencher.

\section{Experimental}

Cholic acid (CA), sodium taurocholate (NaTCA), sodium deoxycholate (NaDCA), dansyl chloride (Dns-Cl), $(S)$-tryptophan (Trp), (S)-tryptophan methyl ester hydrochloride $((S)$-TrpMe $\cdot \mathrm{HCl}),(S)$-acetyl tryptophan methyl ester (AcTrpMe), cholesterol (Ch), lecithin (from fresh egg yolk), $N, N$-(3-dimethylaminopropyl)- $N^{\prime}-$ ethylcarbodiimide (EDC), N,N-diisopropyl- $N$-ethylammine (DIEA), 4-pyrrolidylpyridine (4-Pr-Py), $N, N$ dimethylformamide $(\mathrm{DMF})$, triethylamine $\left(\mathrm{Et}_{3} \mathrm{~N}\right)$ and $\mathrm{NaCl}$ were purchased from Sigma-Aldrich; sodium cholate $(\mathrm{NaCA})$ was provided by Acros Organics. Milli- ${ }^{\circledR}$ water was used in the preparation of aggregates and MM. The derivatives 3 $\beta$-Dns-CA and $\mathbf{7} \boldsymbol{\alpha}$-Dns-CA were prepared as previously reported. ${ }^{22}$ The TLC spots were visualized by spraying the plate with a $10 \% \mathrm{EtOH}$ solution of phosphomolybdic acid followed by heating.

The ${ }^{1} \mathrm{H}$ and ${ }^{13} \mathrm{C}$ NMR spectra were measured by means of a Bruker (Rheinstetten, Germany) $300 \mathrm{MHz}$ instrument; $\mathrm{CDCl}_{3}$ and $\mathrm{CD}_{3} \mathrm{OD}$ were used as solvents, and the signal corresponding to the solvent in each case was taken as the reference: $\mathrm{CDCl}_{3}\left(\delta=7.26\right.$ for ${ }^{1} \mathrm{H} \mathrm{NMR}, \delta=77.2$ for $\left.{ }^{13} \mathrm{C} \mathrm{NMR}\right)$ and $\mathrm{CD}_{3} \mathrm{OD}(\delta=3.31$ for ${ }^{1} \mathrm{H}$ NMR, $\delta=49.0$ for ${ }^{13} \mathrm{C}$ NMR); coupling constants are given in Hz. UPLC MS/MS experiments were performed on a XevoQToF spectrometer connected to the UPLC system through an electrospray ionization (ESI) interface operating in positive ionization mode. Leucine-enkephalin was taken as the lock mass $\left([\mathrm{M}+\mathrm{H}]^{+}\right.$ion $\mathrm{m} / \mathrm{z}$ 556.2771). Separation was carried out on an ACQUITY UPLC HSS T3 C18 column (150 mm x $2.1 \mathrm{~mm}$, i.d. $1.8 \mu \mathrm{m}$ ), maintained at $40{ }^{\circ} \mathrm{C}$. The analysis was performed using a methanol/water mixture (containing $0.01 \%$ formic acid) 20:80 as mobile phase at a flow of $0.2 \mathrm{mLmin}^{-1}$. Exact mass values are included for all new compounds.

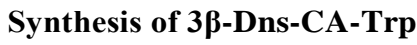


To a solution of $3 \beta$-Dns-CA ( $188 \mathrm{mg}, 0.29 \mathrm{mmol}$ ) in anhydrous $\mathrm{CH}_{2} \mathrm{Cl}_{2}(5 \mathrm{~mL})$, EDC ( $256 \mu \mathrm{L}, 0.32$

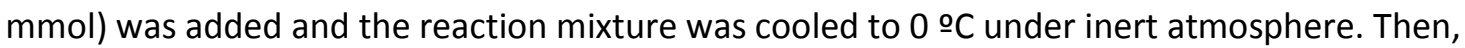
a solution containing (S)-TrpMe $\cdot \mathrm{HCl}(110 \mathrm{mg}, 0.43 \mathrm{mmol})$, DIEA (76 $\mu \mathrm{L}, 0.43 \mathrm{mmol})$ and 4-Pr-Py (21 $\mathrm{mg}, 0.14 \mathrm{mmol}$ ) in anhydrous $\mathrm{CH}_{2} \mathrm{Cl}_{2}(5 \mathrm{~mL}$ ) was added dropwise, and the reaction mixture was stirred overnight at $r t$ in darkness. Afterwards, it was poured into water and extracted with $\mathrm{CH}_{2} \mathrm{Cl}_{2}$. The combined organic layers were washed with brine, dried over $\mathrm{MgSO}_{4}$ and concentrated. Purification by column chromatography $\left(\mathrm{SiO}_{2}\right.$, ethyl acetate/n-hexane, 80:20)

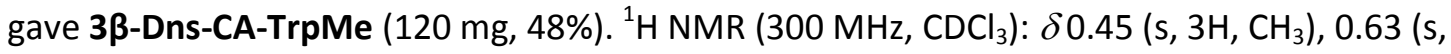
$\left.3 \mathrm{H}, \mathrm{CH}_{3}\right), 0.74\left(\mathrm{~d}, J=5.4 \mathrm{~Hz}, 3 \mathrm{H}, \mathrm{CH}_{3}\right), 2.79\left(\mathrm{~s}, 6 \mathrm{H}, 2 \times \mathrm{CH}_{3}\right), 3.19\left(\mathrm{~m}, 2 \mathrm{H}, \mathrm{CH}_{2}\right), 3.32(b r \mathrm{~s}, 1 \mathrm{H}$, $\mathrm{CH}), 3.54($ br s, $1 \mathrm{H}, \mathrm{CH}), 3.57\left(\mathrm{~s}, 3 \mathrm{H}, \mathrm{OCH}_{3}\right), 3.72(\mathrm{~s}, 1 \mathrm{H}, \mathrm{CH}), 4.85(\mathrm{~m}, 1 \mathrm{H}, \mathrm{CH}), 5.11(b r s, 1 \mathrm{H}$, $\mathrm{NH}), 6.11(\mathrm{~d}, J=8.1 \mathrm{~Hz}, 1 \mathrm{H}$,

NH), 6.85 (s, 1H, Ar-H), 6.94-7.08 (m, 3H, Ar-H), 7.10-7.25 (m, 1H, Ar-H), 7.35-7.46 (m, 3H, Ar-H), 8.14 $(\mathrm{d}, J=6.3 \mathrm{~Hz}, 1 \mathrm{H}, \mathrm{Ar}-\mathrm{H}), 8.21(\mathrm{~d}, J=8.4 \mathrm{~Hz}, 1 \mathrm{H}, \mathrm{Ar}-\mathrm{H}), 8.43(\mathrm{~d}, J=8.4 \mathrm{~Hz}, 1 \mathrm{H}, \mathrm{Ar}-\mathrm{H}), 8.82(b r \mathrm{~s}, 1 \mathrm{H}$, $\mathrm{NH}) ;{ }^{13} \mathrm{C}$ NMR $\left(75 \mathrm{MHz}, \mathrm{CDCl}_{3}\right): \delta 12.5\left(\mathrm{CH}_{3}\right), 17.4\left(\mathrm{CH}_{3}\right), 22.8\left(\mathrm{CH}_{3}\right), 23.2\left(\mathrm{CH}_{2}\right), 25.6\left(\mathrm{CH}_{2}\right), 25.9(\mathrm{CH})$, $27.4\left(\mathrm{CH}_{2}\right), 27.7\left(\mathrm{CH}_{2}\right), 28.5\left(\mathrm{CH}_{2}\right), 30.2\left(\mathrm{CH}_{2}\right), 31.3\left(\mathrm{CH}_{2}\right), 33.0\left(\mathrm{CH}_{2}\right), 33.9\left(2 \times \mathrm{CH}_{2}\right), 34.9(\mathrm{C}), 35.2$ $(\mathrm{CH}), 36.5(\mathrm{CH}), 39.2(\mathrm{CH}), 41.7(\mathrm{CH}), 45.5\left(2 \mathrm{x} \mathrm{CH}_{3}\right), 46.4(\mathrm{C}), 46.9(\mathrm{CH}), 50.2(\mathrm{CH}), 52.4\left(\mathrm{CH}_{3}\right), 52.8$ $(\mathrm{CH}), 68.3(\mathrm{CH}), 72.9(\mathrm{CH}), 109.7(\mathrm{C}), 111.5(\mathrm{CH}), 115.2(\mathrm{CH}), 118.4(\mathrm{CH}), 118.7(\mathrm{CH}), 119.5(\mathrm{CH}), 122.0$ $(\mathrm{CH}), 123.0(\mathrm{CH}), 123.2(\mathrm{CH}), 127.6(\mathrm{C}), 128.3(\mathrm{CH}), 129.5(\mathrm{CH}), 129.7(\mathrm{C}), 129.8(\mathrm{C}), 130.4(\mathrm{CH}), 135.6$ (C), $136.3(\mathrm{C}), 152.0(\mathrm{C}), 172.8(\mathrm{CO}), 173.5(\mathrm{CO})$.

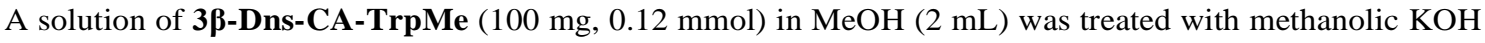
$(1 \mathrm{M}, 1.5 \mathrm{~mL})$ and stirred overnight at $\mathrm{rt}$. Then, the solvent was evaporated, and the mixture redissolved in $\mathrm{H}_{2} \mathrm{O}$, acidified with $\mathrm{HCl}(1 \mathrm{M})$ and extracted with AcOEt. After removal of the solvent in vacuo and purification by column chromatography $\left(\mathrm{SiO}_{2}\right.$, ethyl acetate/n-hexane/AcOH, 80:20:1) 3及-Dns-CA-Trp was obtained (75 mg, 76\%). ${ }^{1} \mathrm{H}$ NMR $\left(300 \mathrm{MHz}, \mathrm{CD}_{3} \mathrm{OD}\right): \delta 0.58\left(\mathrm{~s}, 3 \mathrm{H}, \mathrm{CH}_{3}\right), 0.75\left(\mathrm{~s}, 3 \mathrm{H}, \mathrm{CH}_{3}\right), 0.91(\mathrm{~d}, J=$ $\left.6.6 \mathrm{~Hz}, 3 \mathrm{H}, \mathrm{CH}_{3}\right), 2.88\left(\mathrm{~s}, 6 \mathrm{H}, 2 \times \mathrm{CH}_{3}\right), 3.09-3.18(\mathrm{~m}, 1 \mathrm{H}, \mathrm{CH}), 3.35-3.45(\mathrm{~m}, 2 \mathrm{H}, 2 \mathrm{x} \mathrm{CH}), 3.63($ br s, $1 \mathrm{H}$, $\mathrm{CH}), 3.84(\mathrm{br} \mathrm{s}, 1 \mathrm{H}, \mathrm{CH}), 4.71(\mathrm{dd}, J=8.4$ y $4.8 \mathrm{~Hz}, 1 \mathrm{H}, \mathrm{CH}), 6.96-7.10(\mathrm{~m}, 3 \mathrm{H}, 3 \mathrm{x} \mathrm{Ar}-\mathrm{H}), 7.23-7.34(\mathrm{~m}$, $2 \mathrm{H}, 2 \times \mathrm{Ar}-\mathrm{H}), 7.50-7.62(\mathrm{~m}, 3 \mathrm{H}, 3 \times \mathrm{Ar}-\mathrm{H}), 8.20(\mathrm{dd}, J=7.2$ and $1.2 \mathrm{~Hz}, 1 \mathrm{H}, \mathrm{Ar}-\mathrm{H}), 8.42(\mathrm{~d}, J=8.7 \mathrm{~Hz}$, $1 \mathrm{H}, \mathrm{Ar}-\mathrm{H}), 8.54(\mathrm{~d}, J=8.7 \mathrm{~Hz}, 1 \mathrm{H}, \mathrm{Ar}-\mathrm{H}) ;{ }^{13} \mathrm{C} \mathrm{NMR}\left(75 \mathrm{MHz}, \mathrm{CD}_{3} \mathrm{OD}\right): \delta 12.9\left(\mathrm{CH}_{3}\right), 17.7\left(\mathrm{CH}_{3}\right), 23.3$ $\left(\mathrm{CH}_{3}\right), 24.1\left(\mathrm{CH}_{2}\right), 26.5\left(\mathrm{CH}_{2}\right), 27.3(\mathrm{CH}), 28.5\left(2 \times \mathrm{CH}_{2}\right), 29.6\left(\mathrm{CH}_{2}\right), 31.2\left(\mathrm{CH}_{2}\right), 33.0\left(\mathrm{CH}_{2}\right), 33.9\left(\mathrm{CH}_{2}\right)$, $35.0\left(\mathrm{CH}_{2}\right), 35.2\left(\mathrm{CH}_{2}\right), 36.0(\mathrm{C}), 36.7(\mathrm{CH}), 37.7(\mathrm{CH}), 40.8(\mathrm{CH}), 42.9(\mathrm{CH}), 45.9\left(2 \times \mathrm{CH}_{3}\right), 47.5(\mathrm{C})$, $48.9(\mathrm{CH}), 51.4(\mathrm{CH}), 54.6(\mathrm{CH}), 69.0(\mathrm{CH}), 74.0(\mathrm{CH}), 111.1(\mathrm{C}), 112.3(\mathrm{CH}), 116.4(\mathrm{CH}), 119.2(\mathrm{CH})$, $119.8(\mathrm{CH}), 120.8(\mathrm{CH}), 122.4(\mathrm{CH}), 124.3(\mathrm{CH}), 124.4(\mathrm{CH}), 128.9(\mathrm{C}), 129.0(\mathrm{CH}), 130.3(\mathrm{CH}), 130.9$ $(\mathrm{CH}), 131.0(\mathrm{C}), 131.1(\mathrm{C}), 137.9(\mathrm{C}), 138.0$ (C), 153.0 (C), 175.4 (CO), 176.7 (CO). HRMS: $\mathrm{m} / z$ found 827.4385, calculated for $\mathrm{C}_{47} \mathrm{H}_{63} \mathrm{~N}_{4} \mathrm{O}_{7} \mathrm{~S}\left(\mathrm{MH}^{+}\right)$: 827.4417 .

\section{Synthesis of $7 \alpha$-Dns-CA-TrpMe}

To a solution of $7 \boldsymbol{\alpha}$-Dns-CA (38 $\mathrm{mg}, 0.06 \mathrm{mmol})$ in anhydrous $\mathrm{CH}_{2} \mathrm{Cl}_{2}(2 \mathrm{~mL}), \mathrm{EDC}(56 \mu \mathrm{L}, 0.07 \mathrm{mmol})$ was added, and the reaction mixture was cooled to $0{ }^{\circ} \mathrm{C}$ under inert atmosphere. Then, a solution containing $(S)$-TrpMe $\cdot \mathrm{HCl}(23 \mathrm{mg}, 0.09 \mathrm{mmol})$, DIEA $(16 \mu \mathrm{L}, 0.09 \mathrm{mmol})$ and 4-Pr-Py $(4 \mathrm{mg}, 0.03 \mathrm{mmol})$ in anhydrous $\mathrm{CH}_{2} \mathrm{Cl}_{2}(2 \mathrm{~mL})$ was added dropwise, and the reaction mixture was stirred overnight at $\mathrm{rt}$ in darkness. Afterwards, it was poured into water and extracted with $\mathrm{CH}_{2} \mathrm{Cl}_{2}$. The combined organic layers were washed with brine, dried over $\mathrm{MgSO}_{4}$ and concentrated. Purification by column chromatography $\left(\mathrm{SiO}_{2}\right.$, ethyl acetate/n-hexane, 80:20) gave 7 $\alpha$-Dns-CA-TrpMe $(18 \mathrm{mg}, 36 \%) .{ }^{1} \mathrm{H}$ NMR $\left(300 \mathrm{MHz}, \mathrm{CD}_{3} \mathrm{OD}\right): \delta$ $0.39\left(\mathrm{~s}, 3 \mathrm{H}, \mathrm{CH}_{3}\right), 0.85\left(\mathrm{~s}, 3 \mathrm{H}, \mathrm{CH}_{3}\right), 0.86\left(\mathrm{~d}, J=6.3 \mathrm{~Hz}, 3 \mathrm{H}, \mathrm{CH}_{3}\right), 2.62\left(\mathrm{~s}, 6 \mathrm{H}, 2 \times \mathrm{CH}_{3}\right), 3.01(b r \mathrm{~s}, 1 \mathrm{H}$, $\mathrm{CH}), 3.08-3.18(\mathrm{~m}, 1 \mathrm{H}, \mathrm{CH}), 3.36-3.45(\mathrm{~m}, 1 \mathrm{H}, \mathrm{CH}), 3.71\left(\mathrm{~s}, 3 \mathrm{H}, \mathrm{OCH}_{3}\right), 3.84(b r \mathrm{~s}, 1 \mathrm{H}, \mathrm{CH}), 4.72(\mathrm{dd}, J=$ 9.0 and $5.1 \mathrm{~Hz}, 1 \mathrm{H}, \mathrm{CH}), 6.71(\mathrm{~d}, J=7.2 \mathrm{~Hz}, 1 \mathrm{H}, \mathrm{Ar}-\mathrm{H}), 6.92-7.02(\mathrm{~m}, 2 \mathrm{H}, 2 \mathrm{x} \mathrm{Ar}-\mathrm{H}), 7.08(\mathrm{~s}, 1 \mathrm{H}, \mathrm{Ar}-\mathrm{H})$, $7.20(\mathrm{~d}, J=6.9 \mathrm{~Hz}, 1 \mathrm{H}, \mathrm{Ar}-\mathrm{H}), 7.41(\mathrm{dt}, J=9.0$ y $1.5 \mathrm{~Hz}, 2 \mathrm{H}, 2$ x Ar-H), 7.49 (d, $J=7.2 \mathrm{~Hz}, 1 \mathrm{H}, \mathrm{Ar}-\mathrm{H})$, $8.06(\mathrm{dd}, J=7.5$ y $1.2 \mathrm{~Hz}, 1 \mathrm{H}, \mathrm{Ar}-\mathrm{H}), 8.37$ (d, $J=8.4 \mathrm{~Hz}, 1 \mathrm{H}, \mathrm{Ar}-\mathrm{H}), 8.44(\mathrm{~d}, J=8.7 \mathrm{~Hz}, 1 \mathrm{H}, \mathrm{Ar}-\mathrm{H}) ;{ }^{13} \mathrm{C}$ NMR (75 MHz, CD $3 \mathrm{OD}): \delta 12.7\left(\mathrm{CH}_{3}\right), 17.8\left(\mathrm{CH}_{3}\right), 22.9\left(\mathrm{CH}_{3}\right), 23.5\left(\mathrm{CH}_{2}\right), 27.5\left(\mathrm{CH}_{2}\right), 27.9(\mathrm{CH}), 28.5$ $\left(\mathrm{CH}_{2}\right), 29.2\left(\mathrm{CH}_{2}\right), 31.1\left(\mathrm{CH}_{2}\right), 32.3\left(\mathrm{CH}_{2}\right), 32.6\left(\mathrm{CH}_{2}\right), 34.5\left(\mathrm{CH}_{2}\right), 35.9(\mathrm{CH}), 36.0(\mathrm{C}), 36.4\left(\mathrm{CH}_{2}\right), 39.1$ $(\mathrm{CH}), 40.2\left(\mathrm{CH}_{2}\right), 41.8(\mathrm{CH}), 43.2(\mathrm{CH}), 45.7\left(2 \mathrm{x} \mathrm{CH}_{3}\right), 47.0(\mathrm{CH}), 47.1(\mathrm{C}), 52.7\left(\mathrm{CH}_{3}\right), 52.8(\mathrm{CH}), 55.1$ $(\mathrm{CH}), 72.8(\mathrm{CH}), 73.6(\mathrm{CH}), 111.0(\mathrm{C}), 112.6(\mathrm{CH}), 116.5(\mathrm{CH}), 119.1(\mathrm{CH}), 119.5(\mathrm{CH}), 121.3(\mathrm{CH}), 122.6$ $(\mathrm{CH}), 124.0(\mathrm{CH}), 124.5(\mathrm{CH}), 128.7(\mathrm{C}), 129.0(\mathrm{CH}), 130.5(\mathrm{CH}), 131.0(\mathrm{CH}), 131.2(\mathrm{C}), 131.4(\mathrm{C}), 137.3$ 
(C), 138.2 (C), 153.1 (C), 174.3 (CO), 176.5 (CO). HRMS: $m / z$ found 841.4541, calculated for $\mathrm{C}_{48} \mathrm{H}_{65} \mathrm{~N}_{4} \mathrm{O}_{7} \mathrm{~S}$ $\left(\mathrm{MH}^{+}\right): 841.4574$.

\section{Synthesis of CA-Trp}

A solution of cholic acid $(1 \mathrm{~g}, 2.45 \mathrm{mmol})$ and $\mathrm{EDC}(477 \mu \mathrm{L}, 2.69 \mathrm{mmol})$ in anhydrous $\mathrm{CH}_{2} \mathrm{Cl}_{2}(20 \mathrm{~mL})$ was cooled to $0{ }^{\circ} \mathrm{C}$ under inert atmosphere. Then, a solution containing $(S)$-TrpMe $\cdot \mathrm{HCl}(935 \mathrm{mg}, 3.67 \mathrm{mmol})$, DIEA $(600 \mu \mathrm{L}, 3.67 \mathrm{mmol})$ and 4-Pr-Py $(180 \mathrm{mg}, 1.22 \mathrm{mmol})$ in anhydrous $\mathrm{CH}_{2} \mathrm{Cl}_{2}(30 \mathrm{~mL})$ was added dropwise, and the reaction mixture was stirred overnight at rt. Afterwards, it was poured into water and extracted with $\mathrm{CH}_{2} \mathrm{Cl}_{2}$. The combined organic layers were washed with brine, dried over $\mathrm{MgSO}_{4}$ and concentrated. Purification by column chromatography $\left(\mathrm{SiO}_{2}\right.$, ethyl acetate/n-hexane, 75:25) gave CATrpMe (850 mg, 57\%) as a white solid. ${ }^{1} \mathrm{H}$ NMR (300 MHz, $\left.\mathrm{CD}_{3} \mathrm{OD}\right): \delta 0.68\left(\mathrm{~s}, 3 \mathrm{H}, \mathrm{CH}_{3}\right), 0.93(\mathrm{~s}, 3 \mathrm{H}$, $\left.\mathrm{CH}_{3}\right), 0.99\left(\mathrm{~d}, J=6.3 \mathrm{~Hz}, 3 \mathrm{H}, \mathrm{CH}_{3}\right), 3.08-3.20(\mathrm{~m}, 1 \mathrm{H}, \mathrm{CH}), 3.68\left(\mathrm{~s}, 3 \mathrm{H}, \mathrm{CH}_{3}\right), 3.73-3.80(\mathrm{~m}, 1 \mathrm{H}, \mathrm{CH}), 3.94$ (br s, $1 \mathrm{H}, \mathrm{CH}), 4.74(\mathrm{dd}, J=8.4$ and $5.7 \mathrm{~Hz}, 1 \mathrm{H}, \mathrm{CH}), 6.50(b r \mathrm{~d}, J=5.1 \mathrm{~Hz}, 1 \mathrm{H}, \mathrm{NH}), 6.99-7.12(\mathrm{~m}, 3 \mathrm{H}, 3 \mathrm{x}$ Ar-H), 7.32-7.36 (m, 1H, Ar-H), $7.53(\mathrm{~d}, J=7.8 \mathrm{~Hz}, 1 \mathrm{H}, \mathrm{Ar}-\mathrm{H}), 8.03(\mathrm{~d}, J=5.4 \mathrm{~Hz}, 1 \mathrm{H}, \mathrm{NH})$. A solution of CA-TrpMe $(150 \mathrm{mg}, 0.25 \mathrm{mmol})$ in $\mathrm{MeOH}(3 \mathrm{~mL})$ was treated with methanolic $\mathrm{KOH}(1 \mathrm{M}, 2 \mathrm{~mL})$ and stirred overnight at $\mathrm{rt}$. Then, the solvent was evaporated, and the mixture redissolved in $\mathrm{H}_{2} \mathrm{O}$, acidified with 1 $\mathrm{M} \mathrm{HCl}$, extracted with AcOEt and the solvent removed by vacuum. After purification by column chromatography $\left(\mathrm{SiO}_{2}\right.$, ethyl acetate/n-hexane/AcOH, 80:20:1) CA-Trp was obtained as a white solid (110 $\mathrm{mg}, 75 \%) .{ }^{1} \mathrm{H}$ NMR (300 MHz, $\left.\mathrm{CD}_{3} \mathrm{OD}\right): \delta 0.65\left(\mathrm{~s}, 3 \mathrm{H}, \mathrm{CH}_{3}\right), 0.90\left(\mathrm{~s}, 3 \mathrm{H}, \mathrm{CH}_{3}\right), 0.96(\mathrm{~d}, J=6.6 \mathrm{~Hz}, 3 \mathrm{H}$, $\left.\mathrm{CH}_{3}\right), 3.15(\mathrm{dd}, J=14.7$ and $8.4 \mathrm{~Hz}, 1 \mathrm{H}, \mathrm{CH}), 3.38(\mathrm{~m}, 1 \mathrm{H}, \mathrm{CH}), 3.79(\mathrm{br} \mathrm{s}, 1 \mathrm{H}, \mathrm{CH}), 3.91(b r \mathrm{~s}, 1 \mathrm{H}, \mathrm{CH})$, $4.60(\mathrm{dd}, J=8.4$ y $5.1 \mathrm{~Hz}, 1 \mathrm{H}, \mathrm{CH}), 6.97-7.10(\mathrm{~m}, 3 \mathrm{H}, 3 \mathrm{x} \mathrm{Ar}-\mathrm{H}), 7.32(\mathrm{~d}, J=8.1 \mathrm{~Hz}, 1 \mathrm{H}, \mathrm{Ar}-\mathrm{H}), 7.56(\mathrm{~d}, J$ $=7.5 \mathrm{~Hz}, 1 \mathrm{H}, \mathrm{Ar}-\mathrm{H}) .{ }^{13} \mathrm{C} \mathrm{N}\left(75 \mathrm{MHz}, \mathrm{CD}_{3} \mathrm{OD}\right): \delta 13.0\left(\mathrm{CH}_{3}\right), 17.7\left(\mathrm{CH}_{3}\right), 23.2\left(\mathrm{CH}_{3}\right), 24.2\left(\mathrm{CH}_{2}\right), 27.9$ $(\mathrm{CH}), 28.5\left(\mathrm{CH}_{2}\right), 28.6\left(\mathrm{CH}_{2}\right), 29.6\left(\mathrm{CH}_{2}\right), 31.2\left(\mathrm{CH}_{2}\right), 33.0\left(\mathrm{CH}_{2}\right), 33.8\left(\mathrm{CH}_{2}\right), 35.8(\mathrm{C}), 35.9\left(\mathrm{CH}_{2}\right), 36.5$ $\left(\mathrm{CH}_{2}\right), 36.8(\mathrm{CH}), 40.5\left(\mathrm{CH}_{2}\right), 41.0(\mathrm{CH}), 42.9(\mathrm{CH}), 43.2(\mathrm{CH}), 47.5(\mathrm{C}), 48.0(\mathrm{CH}), 54.6(\mathrm{CH}), 69.1(\mathrm{CH})$, $72.9(\mathrm{CH}), 74.0(\mathrm{CH}), 111.1(\mathrm{C}), 112.3(\mathrm{CH}), 119.3(\mathrm{CH}), 119.8(\mathrm{CH}), 122.4(\mathrm{CH}), 124.3(\mathrm{CH}), 128.9(\mathrm{C})$, 138.0 (C), 175.5 (CO), 176.7 (CO). HRMS: $\mathrm{m} / \mathrm{z}$ found 595.3733, calculated for $\mathrm{C}_{35} \mathrm{H}_{51} \mathrm{~N}_{2} \mathrm{O}_{6}\left(\mathrm{MH}^{+}\right)$: 595.3747.

\section{Preparation of bile salt aggregates}

Aggregates of BSs at different concentrations were freshly obtained by dissolving the appropriate amount of the corresponding salt in aqueous $0.2 \mathrm{M} \mathrm{NaCl}$.

\section{Preparation of mixed micelles}

To a solution of $35.6 \mu \mathrm{mol}$ of lecithin and $77.6 \mu \mathrm{mol}$ of NaCA in methanol $(800 \mu \mathrm{L})$, Ch $(10.8 \mu \mathrm{mol})$

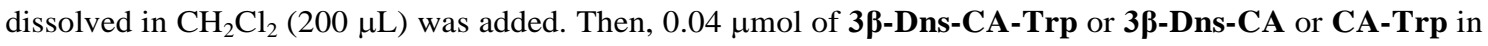
methanol $(100 \mu \mathrm{L})$ was added. The combined solutions were diluted with methanol to reach a total volume of $10 \mathrm{~mL}$ and then concentrated thirty minutes at $50{ }^{\circ} \mathrm{C}$, using a vacuum rotary evaporator and then further thirty minutes at room temperature by means of an oil pump. The resulting dry film was hydrated with 2.74 $\mathrm{mL}$ of $0.2 \mathrm{M}$ aqueous $\mathrm{NaCl}$ to form a clear $\mathrm{MM}$ preparation in which the two channel emitter or the control compounds were at $15 \mu \mathrm{M}$ concentration, ensuring absorbance $<0.1$ at the excitation wavelength.

\section{Photophysical measurements}

UV spectra were recorded on a Cary 300 (Varian) spectrophotometer. Steady-state fluorescence experiments were carried out using a Photon Technology International (PTI, Germany) LPS-220B spectrofluorometer, equipped with a monochromator in the 200-700 $\mathrm{nm}$ range. Time resolved fluorescence measurements were performed with a Time Master fluorescence lifetime spectrometer TM 2/2003 from PTI, using a hydrogen/nitrogen flash lamp as the excitation source. The kinetic traces were fitted by one or two monoexponential decay functions, using a deconvolution procedure to separate them from the lamp pulse profile. For the fluorescence measurements, the concentration of the chromophores was $1.5 \times 10^{-5} \mathrm{M}$, thus ensuring that the absorbance was kept below 0.1 at the excitation wavelength $\left(\lambda_{\text {exc }}=290 \mathrm{~nm}\right)$. Emission measurements were performed in the $330-600 \mathrm{~nm}$ region with excitation in the of $200-340 \mathrm{~nm}$ range. All measurements were performed at room temperature using $10 \times 10 \mathrm{~mm}^{2}$ quartz cells of $4 \mathrm{~mL}$ capacity, under aerobic conditions.

\section{Quenching experiments}

In a typical quenching experiment, the appropriate volumes of a freshly prepared KI solution (2 M) were added to the aerated solutions of the new photoactive probes in the presence or in the absence of the corresponding concentration of BS or MM. 


\section{Acknowledgements}

Financial support from the Spanish Government (CTQ2012-38754-C03-03), Predoctoral FPU fellowship (AP2008-03295), and the Generalitat Valenciana (Prometeo Program) is gratefully acknowledged.

\section{Notes and references}

${ }^{a}$ Instituto Universitario Mixto de Tecnología Química (UPV-CSIC), Universitat Politècnica de València, Avenida de los Naranjos s/n, 46022 Valencia, Spain.

$\dagger$ Footnotes should appear here. These might include comments relevant to but not central to the matter under discussion, limited experimental and spectral data, and crystallographic data.

Electronic Supplementary Information (ESI) available: ${ }^{1} \mathrm{H}$ and ${ }^{13} \mathrm{C}$ NMR spectra for all new compounds; absorption spectra of the probes in solution and in presence of NaCA $300 \mathrm{mM}$; emission spectra of the probes in $300 \mathrm{mM} \mathrm{NaCA}$; fluorescence lifetimes of Trp and Dns chromophores for 3 $\beta$-Dns-CA-Trp, changes in the emission spectra and corresponding Stern-Volmer plots upon increasing [KI] in different media. See DOI: 10.1039/b000000x/

1. I. Vaya, V. Lhiaubet-Vallet, M. C. Jimenez and M. A. Miranda, Chem. Soc. Rev., 2014, 43, 4102-4122.

2. M. Gomez-Mendoza, M. L. Marin and M. A. Miranda, J. Phys. Chem. Lett., 2011, 2, 782-785.

3. M. Gomez-Mendoza, M. Luisa Marin and M. A. Miranda, J. Phys. Chem. B, 2012, 116, 14776-14780.

4. O. L. Waissbluth, M. C. Morales and C. Bohne, Photochem. Photobiol., 2006, 82, 1030-1038.

5. O. Rinco, M. H. Kleinman and C. Bohne, Langmuir, 2001, 17, 5781-5790.

6. S. Mukhopadhyay and U. Maitra, Curr. Sci., 2004, 87, 1666-1683.

7. A. F. Hofmann, Arch. Intern. Med., 1999, 159, 2647-2658.

8. E. Nuin, M. Gomez-Mendoza, I. Andreu, M. Luisa Marin and M. A. Miranda, Org. Lett., 2013, 15, $298-301$.

9. M. A. Hammad and B. W. Muller, Eur. J. Pharm. Biopharm., 1998, 46, 361-367.

10. M. A. Hammad and B. W. Muller, Eur. J. Pharm. Sci., 1998, 7, 49-55.

11. M. A. Hammad and B. W. Muller, Int. J. Pharm., 1998, 169, 55-64.

12. E. Hendradi, Y. Obata, K. Isowa, T. Nagai and K. Takayama, Biol. Pharm. Bull., 2003, 26, 1739-1743.

13. S. Parsaee, M. N. Sarbolouki and M. Parnianpour, Int. J. Pharm., 2002, 241, 185-190.

14. M. A. Hammad and B. W. Muller, Pharmazie, 1998, 53, 790-794.

15. X. Song, Y. Jiang, C. Ren, X. Sun, Q. Zhang, T. Gong and Z. Zhang, Int. J. Nanomed., 2012, 7, 3689-3699.

16. J.-n. Yu, Y. Zhu, L. Wang, M. Peng, S.-s. Tong, X. Cao, H. Qiu and X.-m. Xu, Acta Pharm. Sinic., $2010,31,759-764$.

17. M. Sznitowska, M. Klunder and M. Placzek, Chem. Pharm. Bull., 2008, 56, 70-74.

18. E. Nuin, M. Gomez-Mendoza, M. Luisa Marin, I. Andreu and M. A. Miranda, J. Phys. Chem. B, 2013, 117, 9327-9332.

19. M. C. Cuquerella, J. Rohacova, M. L. Marin and M. A. Miranda, Chem. Commun., 2010, 46, 4965-4967.

20. J. S. Wu, W. M. Liu, J. C. Ge, H. Y. Zhang and P. F. Wang, Chem. Soc. Rev., 2011, 40, 3483-3495.

21. I. Bronshtein, M. Afri, H. Weitman, A. A. Frimer, K. M. Smith and B. Ehrenberg, Biophys. J., 2004, 87, 1155-1164.

22. J. Rohacova, M. L. Marin, A. Martinez-Romero, J. E. O'Connor, M. J. Gomez-Lechon, M. T. Donato, J. V. Castell and

M. A. Miranda, Org. Biomol. Chem., 2009, 7, 4973-4980.

23. T. Forster, Discuss. Faraday Soc., 1959, 27, 7-17.

24. D. F. Eaton, Pure Appl. Chem., 1988, 60, 1107-1114.

25. T. Förster, Modern Quantum Chemistry, Academic Press, New York, 1965. 